\title{
THE DISGUISED OPPRESSION OF INVOLUNTARY GUARDIANSHIP: HAVE THE ELDERLY FREEDOM TO SPEND?*
}

By imposing an involuntary guardianship in the name of help and protection, a court suspends almost entirely an adult's power to create legal relations with other persons. While the ward remains unconfined, and may be left to make many of the non-legal decisions of his daily existence, ${ }^{1}$ he may not direct the disposal or use of his own property, enter valid contracts, marry, change his domicile $^{2}$ or choose agents - doctor, lawyer, or guardian. ${ }^{3}$ Probably he will be unable to write a valid will ${ }^{4}$ and possibly, he will be denied the right to vote. ${ }^{5}$ Involuntary guardianship is imposed upon any adult found to be mentally incompetent. In difficult cases, where mental impairment is not so severe as to make the adult's inability to care for himself or his property patent, a finding of incompetency depends upon a showing of inability to manage property as well as some slight mental weakness or deterioration. Despite the severe incursions of an involuntary guardianship upon individual freedom, courts use non-adversary procedures in adjudicating competency and do not hesitate to impose a guardianship in even doubtful cases. Non-adversary hearings are justified on the ground that only the individual's best interests are at stake $:^{6}$ in theory, there is no one before the court who has an interest adverse to that of the potential ward. But, in fact, there will often be interests quite opposite to those of the potential ward. Relatives, creditors and po-

*In re Tyrell, No. 20467, P. Ct., Preble County, Ohio, aff'd., No. 42, Ct. App., Preble County, Ohio, Oct. 31, 1962, appeal dismissed, 174 Ohio St. 554 (1963).

1. On the legal status of mental incompetents and their loss of civil rights, see generally, Guttmacher \& Weihofen, Mental Incompetency, 36 MINN. L. REv. 179 (1952); Comment, Civil Insanity: The New York Treatment of the Issue of Mental Incapacity in Non-Criminal Cases, 44 CoRnell L.Q. 76 (1958); Shallow, Legal Capacity of Adjudged Incompetents, 29 DICTA 292 (1952).

2. Nor may the guardian change the ward's domicile for him. See, e.g., In re Webber's Will, 187 Misc. 674, 677, 64 N.Y.S. 2d 281, 285 (Surr. Ct. 1946).

3. If an adult grants power of attorney to his lawyer, or agency to manage his property affairs, such relationships are terminated upon an adjudication of incompetency. Therefore, there is no way an adult can plan for and avoid the imposition of guardianship, even by providing for a relationship that provides the same function. Wynn, $A$ Vacutum in Our Law, 95 Trusts \& Estates 879, 881 (1956).

4. For a suggestion that the law requires less competency to draw a will than to assent to contract, see Davidson, An Appraisal of Incompetency, 9 Clev.-Mar. L. Rev. 441, 443 (1960).

5. Lindman \& McIntyre, The Mentally Disabled and the Law 268 (1961).

6. For a discussion of the benevolent purpose of involuntary guardianship as the protection of the ward, see e.g., In re Sariyanis, 173 Misc. 881, 883, 19 N.Y.S. 2d 431, 434 (Sup. Ct. 1940) ; In the Matter of Michelson, 8 Wash. 2d 327, 335, 111 P. 2d 1011, 1015 (1941); In the Matter of Marshall, 15 App. Div. 2d 310, 223 N.Y.S. 2d 207 (1962). 
tential heirs may have reasons to wish wardship imposed. The possibility of conflict and the weaknesses of a non-adversary hearing may best be seen in the treatment of the aged. An elderly individual, having collected considerable funds over a lifetime of savings, may begin to show signs of senility, the inevitable deterioration of old age, as well as a change in consumption patterns. Relatives interested in receiving inheritances may then be able to secure their expectations of inheritance by obtaining the imposition of involuntary guardianship, curtailing the aged's ability to spend what he has amassed. The effectiveness of guardianship for their purposes of estate conservation is enhanced by procedures which favor family interests and offer little real protection to the individual seeking to avoid the imposition of guardianship upon himself.

A recent Ohio case, In re Tyrell, ${ }^{7}$ is illustrative. Walter Tyrell, 85 , had assured his personal security by contracting with a rest home for his care until death $;^{8}$ his burial expenses were pre-paid. ${ }^{9} \mathrm{He}$ had neither living issue nor spouse. In the space of two years, he spent $\$ 9,000$, almost half his remaining estate; two thousand of those dollars were given to a Mrs. Wise, a widowed lady whom he felt "needed it."10 What was left was $\$ 12,000$ of bank stock, snugly bailed to his sister-in-law. It was apparently she who, when return of the stock was demanded, instigated the involuntary guardianship proceedings against Mr. Tyrell. ${ }^{11}$ The hearing which followed was brief. No independent inquiry by court-appointed physicians preceded a finding that $\mathrm{Mr}$. Tyrell was incompetent. Instead the court relied upon the testimony of petitioner's physicians, who had given Mr. Tyrell a fifteen minute examination in the jury room hefore the hearing. ${ }^{12}$ Their evaluation, they admitted, was based on hearsay as well as on their own inquiry. ${ }^{13}$ Although the court recognized that $\mathrm{Mr}$. Tyrell had a good memory and an exceptionally keen, alert mind, it added its own piece of demeanor evidence concerning him: "his smile is at times not normal; his eyes do not focus properly at all times; his gait and reflexes are not normal ; and ... he is not laying his cane aside but dropping it."14 Despite his customary generosity to friends, and his careful planning for his own security, Mr. Tyrell's expenditures of the previous two years were found conclusive evidence of incapacity to manage property. Since Mr. Tyrell had already provided for his own personal care, the only real function of the court-appointed guardian - another relative, Helen Harshman - will be to

7. No. 20467, P. Ct., Preble County, Ohio, aff'd., No. 42, Ct. App., Preble County, Ohio, Oct. 31, 1962, appeal dismissed, 174 Ohio St. 554 (1963).

8. In re Tyrell, No. 42, Ct. App., Preble County, Ohio, October 31, 1962, at 6.

9. In re Tyrell, No. 20467, P. Ct., Preble County, Ohio, at 3.

10. Id. at 2 .

11. Brief for Appellant, p. 8, In re Tyrell, 174 Ohio St. 554 (1963).

12. Mr. Tyrell called upon his personal physician to testify as well. In re Tyrell, No.

42, Ct. App., Preble County, Ohio, October 31, 1962, at 2-4.

13. In re Tyrell, No. 20467, P. Ct., Preble County, Ohio, at 1.

14. Id. at 4. 
conserve the estate, thereby insuring a sizeable inheritance. This result seems to contradict the premises of a doctrine couched solely in terms of benefit to the ward.

Involuntary guardianships have developed, historically, as an almost necessary concomitant to commitment proceedings. ${ }^{15}$ In a society unaware of the many forms of mental illness, guardians were appointed only for the "wildman" who required commitment and restraint. ${ }^{16}$ Once an adult was committed, some method of caring for his property became necessary. Early English law permitted the King to appropriate the entire estate, under the theory of parens patriae; only the profits in excess of an allocation for the support of the ward and his family were conserved for the ward's possible recovery. ${ }^{17}$ Since commitment was then used only in cases of extreme mental disturbance, there was little danger of impinging on freedom to handle property. The impulse for paternal state care was strong. In this country, statutes offered similar protection to lunatics, imbeciles or idiots, ${ }^{18}$ and to the society they endangered. Only recently have the procedures of commitment and the appointment of involuntary guardians been at all separated, ${ }^{19}$ with the courts willing to appoint guardians for those possessing more than a "spark of intelligence." 0

Awareness of the breadth and complexity of the problem of mental illness has wrought many changes: the stigmatized terms of "lunacy, imbecility or idiocy" have been removed from the statutes, and the broader "mentally ill"

15. The early actions were writs of "de lunatico inquirendo" and "deidiota inquirendo." Gutraracher \& Weinofen, Psychiatry and the Law, ch. 14 (1952). The "idiots" or what would today be called "mental deficients," did not always require commitment. The imposition of a guardian, however, was limited to the most severely mental deficient.

16. The adult had to be "so affected as to be dangerous to himself and those around him." In re Cope, 7 Pa. County Ct. 406, 19 Phil. 569, 46 L.I. 497 (1889).

17. M'Elroy's Case, 6 W. \& S. 451,460 ( $\mathrm{Pa} .1843$ ) sketches the historical trends and gradually expanding standards of the law, quoting the early English commentator, Fitzherbert, who defined an incompetent as "one who ... cannot count or number 20 pence, or tell who his father or mother is, or how old he is. ..."

18. See, e.g., Laws of Mass. ch. 38, \& 2 (1783).

19. Commitment is necessary for those adults who require care and treatment, many of whom are still capable of managing their own property affairs, while adults in need of a guardian may not require commitment. This is especially true for the senile, who may need nursing care but can not expect to recover nor respond to mental therapy in existing mental institutions. See Tuma, Civil Rights of the Mentally Ill in Olio, 11 Clev.-Mar. L. Rev. 306 (1962); Note, 41 N.C.L. Rev. 279 (1963); Slovenko \& Super, The Mentally Disabled, the Law, and the Report of the American Bar Foutndation, 47 VA. L. Rev. 1366 (1961). But see Application of Brown, 46 N.Y.S.2d 575 (Sup. Ct.), rev'd, 268 App. Div. 886 (1944); In re Ciena, 10 Misc. 2d 576, 172 N.Y.S.2d 104 (Ct. Cl. 1958).

20. Commonwealth ex rel. Euchenberg v. Schneider, $59 \mathrm{~Pa}$. 328, 330 (1869). The Pennsylvania Supreme Court overruled such a narrow concept of insanity, noting that diseases of the mind were too speculative, so that only capacity to act rationally could be determined. But cf., Commonwealth v. Meredith, 14 W.N.C. 188, 191, 17 Phil. 90, 40 L.I. 64 (1884), a later case, which looked only to see whether there was "present imminent danger that (reason) will be dethroned." 
or "mentally unsound" substituted. ${ }^{21}$ Confinement, a total remedy, is largely reserved for extreme cases; but an adult need no longer be a "gibbering, slobbering, lemon-headed wildman"'22 to be adjudicated mentally incompetent. Modern statutes, sweeping a considerably broader proportion of the population than the early statutes within the disabled class, lay down a Durham ${ }^{23}$ test of civil responsibility: they define a mental incompetent as any person, who by reason of mental illness, mental deficiency, ${ }^{24}$ mental infirmities of old age, ${ }^{25}$ or any other cause, is unable to manage his own affairs or property or is likely to become the victim of designing persons. ${ }^{26}$ Since persons unable to manage

21. Compare Laws of Mass. ch. 38, \$2 (1783) and Mass. Gen. Stat. ch. 109, § \& (1860) with Mass. Ans. Laws ch. 201, 11 (1955).

22. In re Emswiler, S Ohio N.P. 132, 11 Ohio Op. 10 (1901). The amended statutes resulted in a change of attitude, the courts no longer applying guardianship only to the insane but to the general category of the mentally unsound. E.g., In the Matter of Coburn, 165 Cal. 202, 131 Pac. 352 (1913). Mental incompetency now includes the borderline cases that are neither "mens sana nor non compos mentis." Hoffman's Estate, 209 Pa. 357, 359 (1904).

23. Cf. Durham v. United States, 214 F.2d 862 (D.C. Cir. 1954).

24. Mental deficients represent a group more easily identifiable by highly specialized techniques of I.Q. testing than those considered mentally ill. This group, earlier considered "idiots," will not be given consideration here. Generally, a mental deficient or defective is one devoid of minimal reasoning power, usually from birth or early stages of life, as opposed to one who becomes mentally ill.

'[MI]ental defective' shall mean a person who is not mentally ill but whose mental development is so retarded that he has not acquired self-control, judgment and discretion to manage himself and his affairs, and for whose welfare or that of others care is necessary or advisable. The term shall include 'feeble-minded,' 'moron,' 'idiot' and 'imbecile,' but shall not include 'mental illness' and 'senility.'

Pa. Stat. Ann. tit. 50, § 1072(9) (1954); N.Y. Mental Hygrene Law § 2(9). Though included in the general mental incompetency statutes, the mental deficients present special problems and, though trainable, are not curable. For special provisions for care and training, see N.Y. Mental Hygiene LaW \$\$ 120-40.

25. Although senility is a blend of physical and mental deterioration of old age, the imposition of involuntary guardianship is based upon mental incapacity. Some state statutes on their face seem to authorize guardians simply by virtue of old age. See IND. Stat. ANn. tit. 8, $\$ 101$ (c) (2) (1953) (incapability by reason of "old age" as distinct from "senility" or other incapacity); CAI. PROB. CODE $\$ 1460$ (an adult, whether insane or not, who by reason of old age is unable to manage); N.Y. MENTAL HygIENE LAw $\$ 100$ (incapacity of old age). However, almost all the case law interprets such statutory language as requiring a finding of mental incompetency. The rule requiring mental incapacity has been "so long settled and so well known as to be axiomatic." In the Matter of Coburn, 165 Cal. 202, 212, 131 Pac. 352 (1913). There must be "mental incapacity." Ibid. Thus, the courts feel compelled to consider whether the ward is "rational." In the Matter of Towson, 124 Cal. App. 598, 602, 12 P. 2d 1003, 1004 (1932) ; Shafer v. Shafer, 181 Ind. 244, 104 N.E. 507 (1914).

26. The text statement represents a synthesized version of typical state statutes. For a table of each state's statutory definition of mental incompetency, see LINDMAN \& McINtyre, The Mentally Disabled and The Law 230-34 (1961). Occasionally, drug addiction, e.g., PA. Stat. ANN. tit. $50 \$ 1633(3)$ (1954) or chronic alcoholism, e.g., N.Y. Mental Hygtene Law $\$ 100(1)$, are included as causes of incompetency. 
personal affairs will often qualify for confinement, the principal expansion in the statutory standards has been their inclusion of persons who lack capacity only in property management.

In theory, then, mental illness has remained central. ${ }^{27}$ By refusing to appoint guardians for those clearly sane, ${ }^{28}$ despite evidence of "dissipation," wholesale involvement in the wisdom of private expenditures is avoided. Mental illness is used as the justification for the substantial deprivations of liberty involved in imposing guardianship. In practical administration of the statutory rule, however, courts have rendered virtually meaningless inquiry into the causation of erratic conduct. ${ }^{29}$ Psychiatrists rarely testify at guardianship hearings. ${ }^{30}$

27. Statutes may allow involuntary guardianship for the physically incompetent. But a noted state case has held that it would be an unconstitutional deprivation of liberty to appoint a guardian on any other basis than mental incapacity unless the ward consented to guardianship, Schafer v. Haller, 108 Ohio St. 322, 140 N.E. 517 (1923), reprinted with annotation, 30 A.L.R. 1378; In re Irvine, 72 Ohio App. 405, 27 Ohio Op. 332, 52 N.E. 2d 536 (1943), and many state statutes do require consent before appointing guardianship for the physically incapable. E.g., Mass. ANn. Laws ch. 201, $\S \S 1,16$ (1955); Des. Code ANn. tit. 12, ch. 39, \& 3912 (1953). Yet not all states have followed this reasoning, nor all commentators. See Note, 37 HARv. L. REv. 151 (1923). Even if such statutes are considered constitutional, they seem to be an unwarranted restraint on freedom, allowing unrestrained substitution of guardian decision-making for that of the individual. Involuntary guardians for mental incompetents have been justified on the grounds that the individual is no longer capable of formulating decisions for himself, being bereft of reason. While this description of the incompetent may no longer be accurate, given present standards of mental incompetence, it is clearly inapplicable to the physically incompetent.

28. Without evidence of at least some signs of mental weakness, the courts refuse to appoint a guardian even for the old and infirm. See, e.g., In the Matter of Schermerhorn, 277 App. Div. 845, 98 N.Y.S. 2d 367 (1950).

29. See, e.g., In the Matter of Towson, 129 Cal. App. 2d 598, 12 Pac. 1003 (1932) (court relied on petitioner's opinion of mental unsoundness, finding incompetency where aged person gave large gifts to his nurse); In re Wingert, $163 \mathrm{~Pa}$. Super. 616, $63 \mathrm{~A} .2 \mathrm{~d}$ 441 (1949) (despite noting mental alertness, court had no doubt as to senility or mental weakness where aged woman gave $\$ 30,000$ to a couple she lived with).

It is questionable whether the issue of the causal relationship of mental illness to one area of behaviour, such as property management, can ever be resolved. Psychiatrists have long protested their inability to link a criminal act to a mental cause. See, e.g., Szasz, Psychiatry, Ethics and the Criminal Law, 58 CoLum. L. Rev. 183 (1958). Psychiatrists would be even less likely to be able to determine whether property mismanagement was caused by mental illness or merely poor judgment. How much more unreasonable it is to expect a court to make such decisions. Psychiatrists are able to identify the individual so severely mentally ill as to be devoid of all ability to make decisions. However, courts are able to decide such extreme cases unassisted by medical testimony. Where the individual is totally irrational, courts do appoint guardians "preventatively" or "protectively," without any evidence of property mismanagement or dissipation. See, e.g., Sigel Estate, 169 Pa. Super. 425, 429, 82 A.2d 309, 311 (1951); Myers Estate, $395 \mathrm{~Pa}$. 459,150 A.2d 525 (1959).

30. The statutes make medical testimony admissible but not required. Where medical testimony is presented, it is usually that of the family doctor, a general practitioner. 
And courts, once presented with any evidence of mental weakness in any realm of endeavour, immediately turn to evaluate decisions made in the management of property. If they reach a conclusion of mis-management, it is assumed to be the result of the weakness elsewhere discovered, however difficult the connection between the manifested mental unsoundness and the choices made concerning property management. ${ }^{31}$ Property mismanagement thus tends to reinforce and become itself evidence of mental weakness. The requirement of mental illness, then, serves as a stop-gap against involving the "clearly sane" in the process of guardianship rather than as a recognition of the specificity of some mental disabilities.

The result of this development is a greater risk that courts will restrain individuals in their freedom to make legally binding decisions. For the young and middle-aged, the effect of this expansion may not be too great. Because of realistic hopes of recovery from psychological disturbances, courts will hesitate to impose such a restraint. Evidence of mental disability is usually less available, and fewer hovering relatives will seek involuntary guardianship in expectation of personal benefit. For the aged, the possibility of involuntary guardianship imposed for reasons of property mis-management is more troublesome. Given the inevitable and irreversible character of senility, the mental deterioration of old age, evidence of mental illness will virtually always be available. ${ }^{32}$ Thus, although the severity and rate of decline will vary for each individual, ${ }^{33}$ it will often be easy to produce enough evidence of mental weakness $^{34}$ to satisfy the minimal requirements of the courts. Insistence upon even these requirements may be weakened by judicial anticipation that the more usual and milder forms of senility, representing only slight disorientation and occasional lapse of memory - changes not affecting property management abilities - will soon be displaced by acute stages which render the individual

See, e.g., Sigel Estate, 169 Pa. Super. 425, 82 A.2d 309 (1951); In re Stokey, 170 Ohio St. 125, 10 Ohio Op. 2d 16 (1959).

31. See, e.g., In re Tyrell, No. 20467, P. Ct., Preble County.

32. Senility will result in some degree of mental weakness for almost all the aged. See Dovenmuehle, Geriatric Psychiatry, 27 Law \& Contemp. Prob. 133 (1962).

33. Produced by the physical decline of old age, usually by cerebral arteriosclerosis, senility exists in varying degrees of mental incapacity. In its most severe form, senility is a form of psychosis, senility dementia. Noyes, Senile Psychoses, in Modern ClinICAL Psychiatry 236-45 (3rd ed. 1949). In milder forms, senility may mean only a general disorientation or vagueness but need not impair ability of the aged to care for themselves. Knight \& Friedaran, Borderline States, in Psychoanalytic Psychiatry and Psychology 97-99 (1954). Commonly, there is loss of memory for recent events but clear remembrance of the distant past. Interview with Miss Mary Angela Barron, R.N.B.S.N., preparing for M.S.N. in mental health and psychiatry nursing at Yale School of Nursing, New Haven, November 14, 1963. And see In the Matter of Greer, 24 Ohio N.P. (n.s.) 46, 47 (1922).

34. Where there is evidence of property mismanagement, evidence of memory lapses or "infirmities of old age" have been sufficient to convince courts of incompetency. See, e.g., In the Matter of Coburn, 165 Cal. 202, 131 Pac. 352 (1913); Coulter's Estate $406 \mathrm{~Pa} .402,178$ A.2d 742 (1962). 
incapable of caring for his personal needs and devoid of any decision-making capacity.

The problem of using property management as the test of mental incompetency for the aged is complicated by the change in the type of decision an individual makes concerning the expenditure of his estate at the end of his productive years. The aged rarely have legal dependents, their children being past minority and their spouse perhaps deceased. ${ }^{35}$ Without these responsibilities, and facing the prospect of a very short future, they may be more likely, as a matter of conscious decision, to consume at a higher rate while saving less. ${ }^{36}$ They may feel free to spend their entire estate; in anticipation of the disposition of their estate, they may begin to make inter vivos gifts with greater frequency, seeking to distribute their estate while they can still enjoy the gratitude of their beneficiaries and the tax advantages of early dispersal. ${ }^{37}$ Yet judges and juries are likely to measure the aged person's behavior against the norms of middle-aged consumption patterns. The middleaged adult is still the mainstay of his dependent family, a member of the working force, a saver and a planner for the future. His decisions in business, personal consumption and savings are motivated by his present and probable future needs - a consideration no longer pressing for many of the aged, especially if some functional equivalent of an annuity has been reserved from their estates. Ironically, the result of care and foresight in planning for retirement may render the guardian's only substantial duty the preservation for relatives of what was from the start intended as a "spendthrift fund" for carefree years.

Finally, further difficulties for the aged in the property management test are introduced by the fact that evidence of their property decisions almost always involves gift transactions, rarely business mis-management or improvident contracting. In a business context, the courts have a readily available and easily justified norm for judging management of property :88 businessmen are presumed to intend to enter binding agreements and to receive adequate consideration. Yet in the subjective area of gifts, the notion of a deviation from "normal" pattern of behaviour is impossible; even a standard measuring

35. Dodge, Purchasing Habits and Market Potentialities of the Older Consuner, 27 LAw \& Contems. Prob. 142, 146 (1962).

36. Generally, propensity to consume income increases proportionately to savings as income decreases. For the aged, living on smaller incomes, savings will probably be a smaller percentage of income. Individual propensity to consume is affected by changes in the age of the children, and size of any dependent family. See RugGLES \& RUGGLES, National Inconse Accounts and National. Incone Analysis 308 (2nd ed. 1956).

37. Higher death taxes may discourage accumulations of wealth to be transferred after death and instead encourage inter vivos gifts. See TAyLOR, THE Econourres of Public Finance 82 (1953).

38. Compare In the Matter of Coburn, 165 Cal. 202, 131 Pac. 352 (1913) (ward showing signs of memory impaired toward his business dealings with resulting losses, awarded a guardian), with Richardson v. Richardson, 117 Iowa 227, 250 N.W. 897 (1933) (no guardian when evidence of senility but no mismanagement of business). 
deviations from a personal pattern is difficult. The courts have fastened upon a standard of "dissipation," 39 not readily identified with either community or personal norms of behavior, by which they purport to reach decisions with regard to property management.

The chief beneficiary of court use of this standard is the family. "Dissipation" is determined only by the identification of the taker, his worthiness, and, what may be the same, his relationship to the ward. When relatives are the beneficiaries of the aged person's dispositions, the court is less likely to appoint a guardian than when the "attractive young widow" takes, though in both situations evidence of mental unsoundness is similar. ${ }^{40}$ In gifts to the family, the court is not likely to find "necessity" for a guardian, comparing the aged person to the "average man of his years" ;1 mere eccentricity or lapse of memory is not considered sufficient evidence of incompetency to overcome judicial hesitance ${ }^{42}$ to substitute the most "judicious" or "shrewd"43 judgment for the aged's freedom to manage to the best of his ability. When the taker is not a relative, the court is more likely to hold the aged mentally

39. See, c.9., In re Wingert, $163 \mathrm{~Pa}$. Super. 616, $63 \mathrm{~A} .2 \mathrm{~d} 441$ (1949). On superficial observation, the court found Mrs. Wingert to be charming and intelligent; it commented on her mental alertness at the hearing. Nevertheless, on evidence showing gifts of over $\$ 32,000$ to a couple who moved in and promised to take care of her, the court appointed a guardian. It was left with "no doubt . . of senility." Id. at 617. The court compared her generous gifts to her earlier stingy nature. Whether she is "'confused,' 'defective,' 'feeble' or 'weak' is not vitally important. If ... [her] mind is so affected that as a consequence thereof [she] is liable to dissipate or lose property and become the victim of designing persons, the court ... may appoint a guardian." Id. at 620 .

40. Compare In re Gibbons, 183 App. Div. 302, 171 N.Y. Sup. 69 (1918) (occasional lapses of memory and spells making adult temporarily unfit to do business did not prove incompetency; gifts were to daughters) with Gardella v. Gardella, 50 R.I. 210, 146 Atl. 621 (1929) (court noting sound mind but loose behaviour with women found incompetency; aged man was engaged with an antenuptial settlement for $\$ 30,000$ ).

41. See, e.g., In $r e$ Gibbons, 183 App. Div. 302, 171 N.Y. Supp. 69 (1918) (no guardian appointed, despite lapses and spells of aged adult who gave one daughter home in which he resided, other daughter gifts); In re Shelleig, 8 Ohio N.P. 399, 401, 11 Ohio Dec. 1 (N.P. 1901) (no guardian appointed for adult who gave away total assets for $\$ 1.00$ to son's wife and was likely to become a public charge).

42. Where the children are petitioners, however, courts do not hesitate to place the aged person's assets in the conserving hands of a guardian. Thus, the courts continually favor family, either as takers of gifts, or by finding incompetency whenever relatives petition for guardianship, as in the following cases: In re Williams, 24 App. Div. 247, 48 N.Y. Supp. 475 (1897) (93 year old woman with no evidence of mismanagement of property); In re Stokey, 170 Ohio St. 125, 10 Ohio Op. 2d 16 (1959) (despite evidence by three doctors as to competency, son appointed guardian after failing to receive requested loan from aged parent); In re Wilson, 23 Ohio App. 390, 155 N.E. 654 (1926) (no hesitancy to appoint son guardian of 70 year old mother despite absence of evidence of dissipation).

43. In re Brinton, $86 \mathrm{~Pa}$. Super 194 (1926) (no guardian appointed where mother gave gifts and house to daughter; son petitioner); Emerick v. Emerick, 83 Iowa 411, 49 N.W. 1017, 1018 (1891) (capacity to manage property needn't be the "best ability"). 
incompetent, broadening the standard to include any adult subject to the "infirmities of old age." 44

All these dangers sharpen the problems involved in having non-adversary ${ }^{45}$ proceedings, for such proceedings are especially vulnerable to abuse by those who seek guardianship for essentially self-interested, adversary reasons. True, some recognition of the drastic consequences of becoming an adjudicated incompetent is inherent in a presumption of competency ${ }^{48}$ which attaches to every adult. But, in fact, the very structure of the proceedings - as well as judicial adherence to the view that guardianship serves the ward's best interest and lack of sympathy for the unproductive elderly - may encourage a finding of incompetency.

The protection of a burden of proof may not be very significant in proceedings denominated non-adversary. The proceedings, ${ }^{47}$ usually held in county or probate courts, may begin by a petition, ${ }^{48}$ which in many states need not

44. Guardian appointed in all the following cases: Gardella v. Gardella, 50 R.I. 210, 146 Atl. 621 (1929) (ward at 68 had been engaged to a widow, paid antenuptial settlement of $\$ 30,000$, philandered with other women); Fischer v. Adams, 151 Neb. 512,38 N.W. 2d 337 (1949) (guardian appointed in attempt by children to annul 80 year old father's marriage) ; Kutzner v. Meyers, 182 Ind. 669, 108 N.E. 115 (1915) (adult gave estate of $\$ 3,800$ for $\$ 1.00$ to woman who had promised to care for him). However, where the "unworthy" person is petitioner, courts are unlikely to appoint a guardian. See, e.g., Richardson v. Richardson, 217 Iowa 127, 250 N.W. 897 (1933) (petitioner was wife of recent marriage; no guardian appointed) ; Matter of Wilber, 124 Misc. 579, 581, 209 N.W. Supp. 674, 676 (Oswego County Ct. 1925) (court noting that this was a marriage of convenience resulting in "mutual disgust").

45. The proceeding is considered for the ward's benefit only, with all participants in the hearing concerned with his best interests. See, e.g., In re Joyce, 19 Ohio Op. 506, 509, 32 Ohio L. Abs. 553, 557 (P. Ct. 1940) ; Richardson v. Richardson, 217 Iowa 127, 129, 250 N.W. 897, 898 (1933). See Szasz, Civil Liberties and the Mentally Ill, 9 Crev.Mar. L. Rev. 399 (1960).

46. See, e.g., Meyers Estate, 395 Pa. 459, 462, 150 A.2d 525, 526 (1959); In re Schermerhorn, 277 App. Div. 845, 98 N.Y.S. $2 d 367$ (1950). However, this presumption of competency is actually eliminated in the case of voluntary guardianship or conservateur. There, if the ward, after consenting to a guardian, seeks termination, he must prove necessity for guardian no longer exists. In re Barr, 80 Ohio L. Abs. 488, 156 N.E. 2d 357 (P. Ct. 1958). It would seem reasonable to initiate a proceeding for incompetency upon such a request for termination since that issue would not have been passed upon earlier. This would give the adult the protection of a presumption of competency. Else adults might well be deterred from petitioning for such voluntary guardians.

47. Though it is not a constitutional right, jury trial is allowed if requested, by many statutes. For the early English common law affecting constitutional jury right, see Guttmacher \& Weinofen, Psychiatry and the LaW, ch. 14 (1952). New York allows a special jury, or commission in conjunction with a special jury of 12 to 24 men, to examine the allegations of incompetency. N.Y. Mental HygIene LAW $\$ 101(5-6)$.

48. Petition may be by relatives or any other interested persons: CAL. Prob. Conv $\S 1461$ (any relative or friend); IND. Stat. ANN. tit. 8, § 111 (1953) (any person); Mass. ANn. Laws ch. 201, $\S 16$ (1955) (incompetent himself, or one or more of his friends may petition for a "conservator" or a voluntary guardian); DEL. CoDE ANN. tit. 12 , ch. $39, \S 3914$ (Supp. 1962) (relative, a public agency or any person, including the incompetent himself). 
be verified by affidavit or medical certificate. ${ }^{4 \theta}$ If medical certification of the petition is required, that certification may become prima facie evidence of the allegations, shifting the burden of proof at the start. ${ }^{50}$ Once a petition is filed, notice is served to the alleged incompetent; supplemental notice, intended to guarantee against the possibility that the adult will not comprehend notice sent him, is sent to relatives or an official. ${ }^{51}$ But this attempt to assure that there will be some party in court to represent the adult's interests will fail, where, as is often true in the case of the aged, relatives' expectations of nearimmediate testamentary benefit may overcome their sympathy for the testator. ${ }^{62}$

The proceedings are vulnerable to the possible self-interest of the subject's relatives in other ways. If the alleged incompetent is bed-ridden or easily disturbed emotionally, they may be able to convince the court to waive presence. ${ }^{53}$ Despite the practical adversity of the proceedings and the importance of the rights at stake, it is not clear that the alleged incompetent has any assurance of representation. Few states do more than permit appointment of a guardian ad litem $;^{54}$ others explicitly deny the need for such appointment. ${ }^{55}$ Even should the alleged incompetent hire a lawyer to defend him, he may be prejudiced by the nature of the case to be made against him. Evidence at the hearing need not be medical or expert. Though such evidence is frequently admitted, the court has broad discretion whether to appoint its own examiners or to accept evidence presented by the medical experts called by petitioners or the

49. Lindaran \& McIntyre, The Mentaliy Disabled and The Law 239-45 (1961).

50. Cal. Prob. Code § 1461.

51. See Cad. Prob. Code $§ 1461.3$ (notice to Director of Mental Hygiene when alleged incompetent is patient); PA. Stat. ANv. tit. 50, § 3301 (Supp. 1962) (alleged incompetent and all potential intestate successors, any others directed by the court); N.Y. Mental Hygiene LaW $\S \S 101,102$ (the alleged incompetent, spouse, distributees, or persons with whom alleged incompetent resides; when an inmate, to officer of mental institution).

52. An example of possible abuses of the notice requirement shows that relatives, receiving supplemental notice, may be easily able to convince the court to waive presence of the alleged incompetent and to proceed to present only strong evidence of incompetency. Hauser v. Bartow, 273 N.Y. 370, 7 N.E. 2d 268 (1937).

53. Presence is usually required but may be waived, often upon a slight showing that presence would "disturb" the alleged incompetent. CAI. PROB. CODE $§ 1461$ (presence required unless medical certificate shows illness, or alleged incompetent is an inmate); PA. Stat. Ann. tit. 50, § 1681 (1954) (presence required unless testimony shows it may be waived because his welfare would not be promoted by his appearance).

54. See, e.g., Mass. ANN. Laws ch. 201, § 34 (1955) (the court may appoint guardian at litem, but it is not necessary) ; IND. STAT. ANN. tit. 8, § 119 (1953) (if jury is requested, prosecuting attorney shall appear for the alleged incompetent). There is some suggestion that even when guardian ad litem is appointed, that appointment may simply be a "political plum,' assuring only a formal appearance by counsel. Guttmacher \& Weihofen, Mental Incompetency, 36 MinN. L. REv. 179, 183 (1952).

55. See, e.g., PA. Stat. AnN. tit. 50, § 3301 (Supp. 1962) (guardian ad litem unnecessary). New York makes no mention of right to counsel, and Ohio only requires a guardian ad litem in commitment procedures. 
alleged incompetent. ${ }^{56}$ The courts may rely on their own questioning and observation of the alleged incompetent, or upon the testimony of lay witnesses. ${ }^{\text {t7 }}$

The appointment of a guardian virtually insures preservation of the estate for the family of the ward and effectively precludes realization of the ward's possible goals of expenditure and gift of his property. The ward is given no preference in selecting his guardian $;^{58}$ in fact, the nomination of the relatives will usually prevail. ${ }^{59}$ Courts were once suspicious that the next of kin, because of their expectations of inheritance, might not respect their fiduciary duties or might be over-zealous in conserving the ward's estate. ${ }^{60}$ But the family is now presumed to be the most concerned with the ward's well-being, and relatives - even when petitioners - are often appointed guardian, despite their expectations of inheritance. ${ }^{61}$ Even where the guardian is disinterested, the very nature of his responsibility is likely to lead him to favor savings over the consumption pattern which the aged might well be expected to prefer. Based on a presumption that the ward will recover, the statutes focus on protection of property and impose strict fiduciary requirements upon the guardian, ${ }^{62}$ encouraging him to preserve the ward's property ${ }^{63}$ until that event.

56. See, e.g., Matter of Abrams, 25 Misc. 2d 610, 612, 199 N.X.S. 2d 894, 898 (Sup. Ct. 1960). The statutes usually make medical or expert evidence admissible but not required. See PA. Stat. ANN. tit. 50, $\$ 3331$ (Supp. 1962) (testimony of state hospital experts admissible when alleged incompetent is inmate).

57. Lay witnesses may express their opinions, but only when based upon events they have observed. See, e.g., Rhoads v. Rhoads, 29 Ohio App. 449, 452, 163 N.E. 724, $725-26$ (1927).

58. See, e.g., Matter of Coburn, 165 Cal. 202, 218, 131 Pac. 352, 359 (1913) ; Kutzner v. Meyers, 182 Ind. 669, 674, 108 N.E. 115, 117 (1915).

59. See, e.g., Matter of Williams, 252 App. Div. 314, 315, 298 N.Y. Supp. 881. 883 (1937) ; Matter of Kalthoff, 274 App. Div. 881, 82 N.Y.S. $2 d 664$ (1948).

60. For the historical evolution of this presumption against relatives in the role of guardian and the current change to a presumption in their favor, see In the Matter of Pflegher, 62 N.Y. S.2d 899, 901 (Sup. Ct. 1946).

61. Protection of family interests is often coupled with the appointment of relatives, or their nominee, as guardian. But cf., In the Matter of Somarindyck, 158 N.Y.S.2d 208, 210 (Sup. Ct. 1956) (husband's right to inherit was an adverse interest); In the Matter of Sariyanis, 173 Misc. 881, 19 N.Y.S.2d 431 (Sup. Ct. 1940).

62. After posting bond for security, the guardian must present annual accountings and inventories to the court. See, e.g., N.Y. MeNTaI Hygrene LAw $§ 103,110$ (requiring bond and accounting); Oнто REv. CoDE ANN. $\$ 2111.38$ (1954) (requiring bond); $P_{\Lambda}$. Stat. ANN. tit. 50, \$§ 3311, 3313, 3402 (Supp. 1962) (requiring bond, annual accounting, but waiving bond for approved corporate guardians).

63. The powers of the guardian vary slightly from state to state, some allowing him more discretion to sell property than others. See, e.g., NEw York MENTAL HYGrene LAw $\S 106$ (Supp. 1963) (expenditures allowed only for necessities of the ward; investments in approved fiduciary funds; sale of assets prohibited without court order); OnIo REv. CODE ANN. \$§ 2111.13, 2111.14, 2111.20, 2111.25 (1954) (guardian must maintain ward, manage estate, collect debts; he may sell or lease real property without specific court approval); PA. Stat. Awn. tit. 50, \$§ 3401, 3405, 3413, 3441 (Supp. 1963) (guardian may continue ward's business, take possession of property, vote proxies and sell property, all subject to court restraint). 
For expenses beyond the basic necessities, some statutes require the guardian to petition for court approval. ${ }^{64}$ And the guardian is discouraged by court practice from applying to the court for authorization for any such "extraordinary" expenditures. ${ }^{65}$ Using conservative estimates of how long the ward is likely to live, guardians get carried away by a "zeal for fiscal efficiency,"66 providing only the clearest necessities of food, shelter and medicine.

The manner in which guardianship fails to carry through the expressed preference for the welfare of the ward is further seen in the fact that guardianship, concentrating primarily on conservation of property, ${ }^{67}$ neglects the personal care of the ward. Guardianship is relevant only for those aged who have some accumulated savings, and therefore already possess a degree of financial security. ${ }^{68}$ For these aged, the truly pressing need may be for adequate personal attention. ${ }^{69}$ The dominance of the financial aspects of guardianship is particularly revealed by those statutes which allow a corporation to be appointed as guardian. ${ }^{70} \mathrm{~A}$ large, impersonal trust company may be competent to manage property, but it is doubtful that it will be sensitive to the daily needs of any given ward. Finally, the dominance of the financial aspect of guardianship may well be unrealistic to the extent that the ward's possible recovery is contemplated. Although, in theory, the aged ward may terminate his guar-

64. Compare N.Y. Mental Hygiene LAw $\$ 106$ (Supp. 1963) (allows provision of necessaries, any further expenses requiring court approval), with Oryo Rev. Code ANN. $\$ 2111.13$ (1954) (allowing any suitable maintenance, prohibiting only the use of principal without court approval).

65. Even when guardians petition for court approval of expenditures, courts refuse to render any decision, believing that guardians as arms of the court, must assume their rightful duties. For any serious mistake, however, the guardian will be liable on his bond. Therefore, he is encouraged to adhere to conservative expenditures. See, e.g., In the Matter of Hagedorn, 176 Misc. 233, 27 N.Y.S. 2d 48 (Sup. Ct. 1941) ; In re Muck, 125 N.Y.S. 2d 415 (Sup. Ct. 1953).

66. In the Matter of Danzig, 23 Misc. 2d 591, 196 N.Y.S. 2d 211, 214 (Sup. Ct. 1960).

67. See, e.g., In re Marshall, 67 Ohio L. Abs. 314, 120 N.E. 2 d 324 (Ct. App. 1951) (the principal reason for guardianship is to conserve the estate).

68. Unless the adult has some minimum amount of assets, a guardian need not be appointed at all. The entire estate may be held or disposed of by the person or institution maintaining the incompetent. PA. STAT. ANs. tit. 50, § 3201 (Supp. 1962) which, in 1955, amended the smaller $\$ 1,500$ figure to $\$ 2,500$. The Ohio figure, previously $\$ 500$, now requires a minimum estate of $\$ 1,000$ before guardian is appointed. The statute enables the court to authorize the placing of the estate in a suitable depository, while retaining control of its disposition. OHro Rev. CoDE ANN. $\$ 2111.05$ (Supp. 1963).

69. Although it is anticipated by statutes and courts that guardians will minister to personal as well as financial needs, the statutes establish no criteria for what is adequate personal care. The courts, concentrating on the fiduciary aspects of guardianship, abdicate supervision of personal care completely to guardian. Cases cited note 10 supra. But cf., In the Matter of Nutting, 74 App. Div. 468, 77 N.Y. Supp. 696 (1902) (court requiring more adequate personal care of ward, during an intermediate accounting).

70. See, e.g., Pa. Stat. Ann. tit. 50, § 3313 (Supp. 1962). But see Ohro Rev. Code ANN. $\$ 2111.10$ (1954) which allows corporations to be guardians only of the estate, and not of the person. 
dianship at a second court hearing, ${ }^{71}$ it is extremely unlikely that he will ever be able to prove that the necessity for a guardian no longer exists. ${ }^{72}$

As applied to the aged, then, the institution of involuntary guardianship often serves to favor family interests ${ }^{73}$ even though it is rationalized solely in terms of the interests of the ward. Of course, court favoritism for family interests could be defended as an attempt to preserve the integrity of the ward's intent. The ward would not want to act "foolishly" and the court aids him in fulfilling his desire. Such a defense is often used in analyzing court questions of testamentary capacity. Here also, courts protect those who would ordinarily be heirs but they disavow this function ${ }^{74}$ under the guise of sanctifying the integrity and freedom of testator's intent. ${ }^{75} \mathrm{~A}$ decedent will be said to have had testamentary capacity at the time he wrote his will, if he was able to comprehend the extent of his property and was aware of those who were the "natural objects of his bounty." Since the testator is necessarily absent from the courtroom, the focus of court inquiry is even more sharply on the character of his dispositions. When the disposition is "unnatural," i.e., when it goes to a taker other than relatives, the testator is often deemed mentally incapable of having drawn a valid will. ${ }^{77}$ Yet if the testator's intent is presumed always to involve adherence to the societal norm of dispositions within the family, express statements that he is free to dispose of his property

71. See, e.g., Cal. Prob. Cone, $\$$ 1470-72; N.Y. Mental Hygrene Law \$ 112 (Supp. 1963) PA. Stat. AnN. tit. 50, § 3321(6) (Supp. 1962).

72. The ward would have to show improvements in his mental condition and his ability to manage property. Senility, unlike other forms of mental illness, is not subject to recovery, and is only likely to become more severe. Compare Smith v. Smith, 26 Ohio Op. 541, 38 Ohio L. Abs. 503, 12 Ohio Supp. 101 (P. Ct. 1943), with In re Guardianship of Nitschke, 113 Ohio App. 243, 17 Ohio Op. 2d 223, 177 N.E. $2 d 628$ (Ct. App. 1961). And it seems absurd to expect the ward to show a change in ability to manage property, when, under guardianship, he no longer has the opportunity to make any property decision. It is therefore improper to treat guardianship as an interim custody, in the case of the aged, intended to conserve property for the ward until such time as he can do what he wishes with it.

73. One court went so far as to equate the involuntary guardian of the aged adult to the executor of a decedent's estate. In the Matter of McCarthy, 279 App. Div. 716, 719, 108 N.Y.S. 2d 439, 443 (1951). Another court admitted that guardianship preserved the estate for the ward's life and his family afterward. Hoffman's Estate, $209 \mathrm{~Pa}$. 357, 360, 58 At1. 665, 666 (1904).

74. The implication that the estate of the aged ward was being preserved for the son was "unacceptable," even though the court recognized it was a likely result. In the Matter of Marshall, 15 App. Div. 2d 310, 223 N.Y.S. 2d 207 (1962) ; In re Cook, 53 Hun. 634, 6 N.Y. Supp. 720 (N.Y. 1889).

75. Yet the one significant anti-intent doctrine is the test for testamentary capacity. See Gulliver, Cases and Other Materials on The Law of Estates: Gratuitous Transfers 161-88 (Clark, rev. ed. 1963) (unpublished materials in Yale Law School Library).

76. Green, Proof of Mental Incompetency and the Unexpressed Major Premise, 53 Y ALE L.J. 271, 277 (1944).

77. Id. at 299-302. The terms of the will itself may become evidence of incompetency. While "lip-service" is paid to testator's intent, the family is protected as a social institution. 
as he wishes must be disbelieved. Freedom to neglect family expectations necessarily implies ability to depart from the norm. If each deviation from the norm is construed as evidence of non-intent, clearly freedom to dispose of property is curtailed in favor of the protection of the family. The argument that the judicial attitudes are defensible as an attempt to preserve the ward's intent, then, fails.

The consistency with which these family interests are favored suggests that there may be some reason to consider inheritance expectations as worthy of protection. True, these interests have been characterized as "mere" expectations, ${ }^{78}$ a "bright hope" undeserving of legal recognition. But such characterizations have arisen more out of distaste for negotiation and assignment of inheritances than out of respect for testamentary freedom. ${ }^{79}$ In fact, such expectations are protected both explicitly, as in the widow's elective share, ${ }^{80}$ and tacitly, as in the area of testamentary capacity, through standards which favor intestate succession whenever "unworthies" appear to be takers. A similar result is achieved in the imposition of involuntary guardianship where the existence of "dissipation" is tested by the "worthiness" of the taker. ${ }^{81}$ Antipathy to avaricious young ladies is not the sole cause for family preference. Much of the aged individual's property may have been secured by the joint efforts of family members, or inherited from common ancestors. It is not entirely accurate to say that what the individual owns, he owns entirely by his own initiative; many will have participated directly in the creation of his property. As against his claim to do with what is his as he will, these persons - in more-or-less accurate statistical shorthand, his family - have a claim that the property is not entirely his. It may be rational to favor the family, at least whenever the individual can be shown incapable of exercising his will. This is the effect of the law of involuntary guardianship as well as that of testamentary capacity.

If such a balance of interests is to be struck, it should be struck openly, so that courts can reason and express their results in terms of the family as well as the individual interests involved. It might then appear relevant whether the relatives who would benefit by the guardianship were so close to the individual that it could be said fairly that they had shared, in some way, in the creation of his estate, or had justifiable expectations about the flow of

78. E.g., In re Garcelon's Estate, 104 Cal. 570, 575, 38 Pac. 414, 417 (1894).

79. Cf. Lucena v. Crauford, 2 B. \& P.M.R. 269, 127 Eng. Rep. 630 (House of Lords 1805).

80. E.g., New York Decedents Estate Law $\$ 18$.

81. It is predictable that if a taker other than family were considered "worthy," the courts would not find dissipation. Thus, where the gifts are to charity, a guardian may not be considered necessary. See, e.g., In re Guardianship of Smith, 26 Ohio N.P. (n.s.) 533 (P. Ct. 1927) (not a waste of property for aged to give to charities, even though retrieving stocks he had given to his son); In the Matter of Burke, 125 App. Div. 889, 110 N.Y. Supp. 1004 (1908) (95 year old woman with extreme senility not awarded guardian, her will leaving entire estate to charity). 
property from some common ancestor. And the present court practice of using neglect of family interests to prove the need for their protection would properly be restricted by a straightforward recognition by the courts that they are resolving a balance of adverse interests. Such a balance ought strongly to favor the individual in every case: freedom to deviate from norms of societal behavior is too important an aspect of our societal structure to be sacrificed to any but the most pressing of demands or the most clear evidence of mental incapacity. ${ }^{82}$ This is particularly the case with involuntary guardianship. Unlike a conclusion of testamentary incapacity, imposition of a guardianship results in an immediate and significant loss of freedom and dignity for the individual subject to its consequences.

Societal interests in involuntary guardianship, as distinct from family or personal interests, are of limited scope. If the goal is to protect society from dangerous individuals, confinement rather than involuntary guardianship would be the only satisfactory solution. If society is to be protected against bearing the welfare costs of persons who destitute themselves by dissipating their savings, this goal may be accomplished without the substantial incursions on individual freedoms represented by guardianship. Enforced savings programs such as social security may be used to assure steady sources of income for all the aged. Many aged, like Mr. Tyrell, will already have provided for necessary security, and will not require the state's assistance. Society's interest in this respect, moreover, applies equally to all those who might become destitute - not only the mentally weak - and ceases once destitution is shown to have been avoided. It thus fails to explain the stringencies of involuntary guardianship upon private property control. Society does use involuntary guardianship to further certain moral judgments and social norms. The very preference for family and the characterization of who is an "unworthy" taker are expressions of general community attitudes. A preference for youth or an intolerance of the aged and their burdensome and "eccentric" behavior may also be implicit in the imposition of involuntary guardianship. But if faced squarely with the question whether these implicit preferences or intolerances were to be enforced through explicit recognition of involuntary guardianship proceedings as adverse to the individual, it seems unlikely that courts or legislatures would often choose against the individual.

If involuntary guardianship should only be imposed in the interests of the ward, inability to manage property should not be sufficient grounds for imposition. Without a suggestion of mental weakness, there is no justification for protecting adults who can not manage property. Prevailing values allow an adult freedom to dispose of property as he wishes, and if he should choose to beggar himself or simply persist in bumbling through life, the law does

82. Eccentric or annoying behaviour ought to be tolerated as much as possible in a pluralistic society. Szasz, Civil Liberties and the Mentally Ill, 9 Cr.zv.-Mar. L. Rev. 399 (1960). Unless based on mental incapacity, involuntary guardianship would be a serious deprivation of an adult's "free and normal exercise and use of his personal conduct, liberty and property. ..." In re Ginnel, 43 N.Y.S. 2d 232, 235 (Sup. Ct. 1943). 
not intervene paternally. Instead, society has chosen to retain a wide arena of unfettered freedom of decision despite the costs of mistakes and mismanagement. So long as evidence of property mismanagement is treated as suffcient for a finding of mental illness, preference for individual freedom and decision-making will be defeated.

The aged do have some interest in financial security, and, possibly, they are more easily defrauded. But financial security may be assured while allowing the individual a maximum of integrity and freedom. General savings plans, enforced for all members of society, as social security, insure at least some income for all the aged. ${ }^{83} \mathrm{~A}$ court order requiring purchase of an annuity or the establishment of a personal trust fund would insure security without deprivation of the adult's legal rights. The adult would be free to dispose of the insured income and whatever excess assets he retained. If there was strong suspicion that the annuitant was mentally ill, his conduct in disposing of the income might be final evidence of incompetence vel non. If he failed to use the income for his own welfare, his shelter, food and medicine, a court might order more drastic interference. As far as fraud is concerned, it seems too drastic to prevent inchoate schemes by imposing a total disability from dealing with any people. The alternative approach, to take action against persons guilty of fraud, though perhaps less effective, seems preferable in its respect for individual freedom. ${ }^{84}$

As applied to adults truly incapable of making any decisions, the structure of guardianship should be amended to insure protection of the ward's real needs. An important need, presently unstressed by the law, is the need for personal care. Geriatric facilities are presently insufficient. An individual should be able to volunteer his need for personal help and to refuse it when he was already blessed with sufficient nurses, housemaids and doctors ;85 likewise, where the need is for assistance in property management. Legal interference would be superfluous and officious. What the elderly need is a com-

83. In 1961, social insurance covered $12,430,000$ of the $17,130,000$ people over the age of 65. U.S. Dept. of Commerce, Statistical Abstract of the United States 280 (1962). Although the recent Medicare proposal was defeated, it is reasonable to expect similar legislation to provide assurance of medical expenses to as many of the aged in the near future. Hearings Before Honse Committee on Ways and Means on Health Services for the Aged Under the Social Security and Insurance System, 87th Cong., 1st Sess., vols. 1-4, (1961) ; Epstein \& Gallison, Financing Health Care for the Aged, 27 Law \& Contearp. Prob. 102 (1962).

84. It is to be remembered that the question of competency will often be raised in reaction to, rather than anticipation of fraud, so that the protection to be offered is not so great as might first appear. And there is no ready way to identify designing behaviour without implying the same societal standards of morality and choice which ought not to apply in judging the validity of property transactions.

85. In a few cases, the courts have not appointed guardians for the extremely senile when their security was assured. This would allow the aged to plan for their own future and avoid guardianship if well provided for. See, e.g., In re Brown, 119 Misc. 198, 196 N.Y. Supp. 200 (Sup. Ct.), rev'd, 203 App. Div. 869, 196 N.Y. Supp. 918 (1922) (per curiam); In re Wells, 177 App. Div. 100, 163 N.Y. Supp. 826 (1917). 
fortable level of existence, not the preservation of the estate for the event of their recovery. Thus, the guardian of the estate should not be a possible heir with an interest adverse to expenditure. And he should be permitted to pay out for more than basic necessities, free from rigorous fiduciary standards.

The reforms suggested require considerable reworking of the institution of guardianship. To maximize the possibilities for personal care and financial supervision sensitive to the aged ward's needs, it would be wise, where possible, to appoint separate guardians of the person and of the estate. The family will often prove the most fruitful source of a guardian for the ward's personal needs, but not for his financial needs. Periodic medical examinations or visits by a social worker might be required to supervise the ward's personal care. Furthermore, improvements should be made in the hearing procedure. Medical testimony by impartial, preferably court appointed, physicians should be ordered before concluding that the adult cannot care for himself. Adversity should be recognized partly by making sure the potential ward is represented by counsel - court appointed, if necessary. It will be recognized that all these conclusions, like many reached above, apply with like force at whatever age level guardianship is applied, for at all levels the institution presents similar dangers. ${ }^{86}$ In the particular case of the aged, the court must be sensitive to the role of guardianship as but one part of an overall concern for their welfare. As specialized facilities such as cottage communities and geriatric nursing homes become increasingly available, ${ }^{87}$ commitment, allowing ambulatory freedom but providing personal care, will become a more effective institution for the aged. ${ }^{88}$ As commitment may become more prevalent, guardianship, once historically linked to commitment, may again become an integral part of such procedures. Commitment may become the means of assuring personal care of the aged ward, while guardianship, as a supplement, could fill the function it best serves, the management of property.

86. It may well be, however, that courts are more hesitant to impose guardianship upon the younger or middle-aged adult. The procedures and standards themselves do not make any such distinction, nor offer greater restraints upon such imposition. Therefore, though judicial attitudes may make abuses less frequent, improper application of guardianship is nonetheless possible.

87. In 1956, New York established a special consultant on services for the aged to investigate and make recommendations on the need for expanded geriatric facilities. N.Y. Mental Hygiene Law § 3-a (Supp. 1963).

88. The extremely senile require specialized care but commitment to existing institutions does not meet their needs; mental therapy and analysis emphasize recovery, unsuitable for the physically based senility psychosis. See two decisions by Justice Brenner, who reuctantly committed aged to mental hospitals simply because no other facilities were available. In the Matter of "Anonymous \#1," to "Anonymous \#12," $206 \mathrm{Misc}$. 909, 138 N.Y.S. $2 \mathrm{~d} 30$ (Sup. Ct. 1954) ; In the Matter of "Anonymous \#13," 6 Misc. 2d 596, 159 N.Y.S. 2d 842 (Sup. Ct. 1957). 